\title{
OTC Gene
}

National Cancer Institute

\section{Source}

National Cancer Institute. OTC Gene. NCI Thesaurus. Code C75882.

This gene is involved in the regulation of the uric acid cycle. 